\title{
In memoriam Professor Ugo Efisio Francesco Carcassi
}

I am very sad to report the passing away of Professor Ugo E.F. Carcassi, a great man, internist, rheumatologist, and co-founder of the European integration of medical sciences. He passed away in his home city, Cagliari, on the 16 $6^{\text {th }}$ of May, 2016.

Professor Ugo Efisio Francesco Carcassi was Sardinian; he was born in Cagliari on the $21^{\text {st }}$ of August 1921. He was admitted to the Medical Faculty at the old University of Sassari in Sardinia (Università degli Studi di Sassari), but the outbreak of the Second World War interrupted his studies. He was a volunteer in a military hospital in North Africa, and after the war returned to the school and graduated medicine summa cum laude in 1946. After graduation, he worked at the University of Siena (Università degli Studi di Siena) (as a teacher of se-

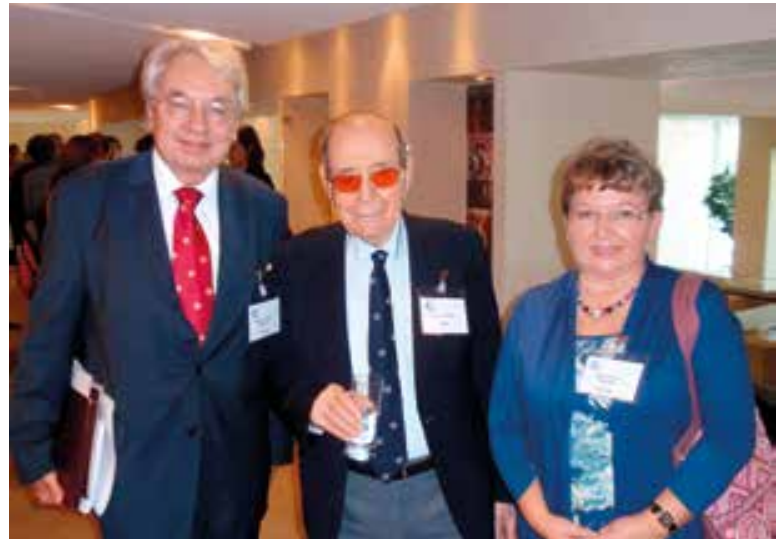

Photo. Athens, October 6, 2011. From left: Eugeniusz J. Kucharz, Ugo E.F. Carcassi and Anna Kotulska miotics and infectious diseases), later returning to his native island Sardinia, and was a professor of pathology and clinical medicine in Cagliari (Università degli Studi di Cagliari). He was also an instructor of rheumatology at the La Sapienza University in Rome (Università degli Studi di Roma La Sapienza). During his professional career, Professor Carcassi was a few times a visiting scientist, e.g. in Victoria University in Manchester (1952, 1957 the United Kingdom - studies on bacteriology and viral myocarditis), the University of Columbia (1962, New York, USA - studies on bone marrow transplantation).

Research activity of Professor Carcassi was focused on several important areas of medicine, including rheumatology. He carried out significant studies on thalassemia, malaria and favism. In 1951, he was the first to describe an inherited anemia similar to favism but induced by pea consumption (Il Progresso Medico - Napoli, 1951; 7: 214-217), i.e. pisellism. He was a founder and the first director of the National Italian Council of the National Institute for Thalassemia and Mediterranean Anemia in Cagliari (Consiglio Nazionale delle Ricerche Italiano, dell'Istituto di Ricerche sulla Talassemia ed Anemie Mediterranee a Cagliari). He authored a great number of publications, including studies on pharmacotherapy of rheumatic disease and antiphospholipid syndrome.

He was interested in the history of medicine, investigating health and diseases of such famous historic persons as Christopher Columbus, Giuseppe Garibaldi, Niccolò Paganini, Giacomo Casanova, and others. During the EFIM Congress in Rome, I received from Professor Carcassi his book that was a translation from Latin of the first treatises on preventive medicine ("Liber conservanda sanitate") written by Peter of Spain, known as Pope John XXI (the only pope that was a physician as well).

Professor Carcassi contributed significantly to foundation of the European associations of internists. He was a president of the Association Européenne de Médecine Interne d'Ensemble (1989-1994), and he initiated changes in this society that had been a personal association of European internists. Due to his initiative, the Forum of Presidents of national societies of internal medicine was founded, and English was introduced as the main language of the society. In 1996, during the meeting in Paris, the former association was transformed into the European Federation of Societies of Internal Medicine. Professor Ugo Carcassi became an honorary president of the federation. In 1989, Professor Ugo Carcassi founded a new journal, the European Journal of Internal Medicine, and became its first editor-in-chief.

Professor Carcassi was awarded a number of scientific and state honors, including membership of the New York Academy of Sciences (1983), the Royal Society of Medicine (1980), the Royal College of Physicians in London (1997) and the Indian Rheumatism Association (1988). He received an honorary award of the Rotary Club in Cagliari.

Professor Ugo Carcassi was a great personality. In 2013, his book "Un medico in Sardegna" appeared in print. It is an interesting account on his professional life and development of medicine of the $20^{\text {th }}$ century. 
Professor Ugo Carcassi was an excellent speaker and an interesting, open-minded man. I remember very well numerous discussions with him on medicine and people living in Sardinia, the island that was his home and my favorite vacation location. We even had the same beloved small gulf on the island, Golfo di Arancia. The Polish Society of Internal Medicine awarded Professor Ugo Carcassi with the Centenary Medal, and Dr Anna Kotulsa and I had the honor to present the medal to Professor Carcassi. We met for the last time in Athens in 2011, during the Congress of the European Federation of Internal Medicine organized 15 years after Ugo E.F. Carcassi had declared foundation of the Federation, which also happened in Athens.

Professor Ugo Efisio Francesco Carcassi was a unique great mind of medicine. He understood the holistic approach to a patient and considered internists from various countries as colleagues. His works and organizational efforts have a firm position in modern medicine, and he will be sorely missed.

Eugeniusz J. Kucharz 